\title{
PENGARUH PENGGUNAAN METODE QUANTUM LEARNING TERHADAP KEMAMPUAN KOMUNIKASI MATEMATIS SISWA PADA MATERI FUNGSI DAN RELASI DENGAN MNGGUNAKAN ALAT PERAGA DI KELAS X SMK NEGERI 1 STABAT TAHUN PELAJARAN 2019/2020
}

\author{
Rio Pramudya ${ }^{1)}$, Ice Wirevenska, M.Pd ${ }^{2)}$, Dewi Rulia Sitepu, M.Si ${ }^{3)}$ \\ 1) Mahasiswa STKIP Budidaya Binjai Prodi Pendidikan Matematika \\ (e-mail : pramudyario9@gmail.com ${ }^{1)}$,(e-mail : ice.wr08@gmail.com) ${ }^{2}$, \\ (e-mail : $\underline{\text { dewiruliasitepu@gmail.com })^{3)}}$
}

\begin{abstract}
ABSTRAK
Penelitian ini bertujuan untuk mengetahui pengaruh metode quantum learning dengan menggunakan alat peraga terhadap kemampuan komunikasi matematis siswa kelas X SMK Negeri 1 Stabat tahun pelajaran 2019/2020. Penelitian ini menggunakan metode quasi eksperimen (eksperimen semu) dan desain yang digunakan adalah pretest- posttest control goup design. Sampel dalam penelitian ini adalah kelas X-1 AK sebagai kelompok eksperimen dan kelas X-2 AK sebagai kelompok kontrol yang masing-masing berjumlah 30 orang siswa. Berdasarkan hasil analisis data diketahui bahwa nilai rata-rata kemampuan komunikasi matematis siswa kelompok kelas eksperimen setelah mengikuti serangkaian proses pembelajaran dengan metode quantum learning dan alat peraga mengalami peningkatan yang sangat signifikan yakni 40,3 meningkat menjadi 82.2 dan tidak terdapat peningkatan yang signifikant pada kelompok kelas kontrol yang menggunakan model pembelajaran konvensional yakni 41,47 menjadi 43,87. Sehingga dapat diambil kesimpulan bahwa terdapat pengaruh metode quantum learning dengan menggunakan alat peraga terhadap kemampuan komunikasi matematis siswa kelas X SMK Negeri 1 Stabat tahun pelajaran 2019/2020.
\end{abstract}

\section{Kata kunci: Quantum Learning, Alat Peraga, Kemampuan Komunikasi Matematis}

\section{PENDAhuluan}

Menurut Dharma (2019) matematika merupakan ilmu universal yang mendasari perkembangan teknologi modern, mempunyai peran dalam berbagai disiplin dan memajukan daya pikir manusia. Tujuan peserta didik mempelajari matematika adalah untuk dapat memahami konsep, menyelesaikan masalah sistematis, mengaitkan matematika dengan kehidupan sehari-hari dan dapat mengungkapkan ide-ide matematisnya dengan baik secara lisan maupun tertulis.

Matematika merupakan salah satu bidang studi yang menduduki peranan penting dalam dunia pendidikan, karena dalam pelaksanaannya pelajaran matematika diberikan di semua jenjang pendidikan. Hal ini sesuai dengan UndangUndang Republik Indonesia nomor 20 tahun
2003 pasal 37 tentang Sistem Pendidikan Nasional (Depdiknas: 2003) yang menyatakan bahwa salah satu mata pelajaran yang wajib diberikan pada jenjang pendidikan dasar dan menengah adalah mata pelajaran matematika.

Bagi dunia keilmuan, matematika memiliki peran sebagai bahasa simbolik yang memungkinkan terwujudnya komunikasi secara cermat dan tepat. National Council of Teachers of Mathematics (NCTM, 2000) merumuskan tujuan pembelajaran matematika yaitu salah satunya adalah belajar untuk berkomunikasi (mathematical communication). Komunikasi matematis adalah kemampuan peserta didik untuk menyatakan ide-ide matematika baik secara lisan maupun tertulis. (Hartini), Sesuai dengan Kurikulum 2013 dan Kurikulum Tingkat Satuan Pendidikan, salah satu kemampuan 
matematis sesuai dengan standar proses yang harus ada pada peserta didik adalah kemampuan komunikasi matematis.

Pengamatan yang dilakukan oleh peneliti saat PPL terlihat bahwa proses pembelajaran matematika di kelas X SMK Negeri 1 Stabat Kabupaten Langkat umumnya masih bersifat konvensional, di mana proses belajar mengajar hampir selalu berlangsung dengan metode konvensional. Tampak bahwa pembelajaran belum berpusat pada siswa (student centered learning). Siswa menerima materi yang disampaikan oleh guru secara aktif dengan mencatat, mendengar dan hanya sesekali terdapat siswa yang mencoba untuk bertanya terkait dengan materi tersebut. Hari Suderadjat (2004 : 8), Umumnya siswa masih berperan sebagai objek pembelajaran, belum sebagai subjek pembelajaran. Suderadjat menyebutkan bahwa proses pembelajaran yang lebih didominasi pada cara penyampaian informasi (transfer of knowledge) dan cenderung sebagai proses menghafalkan teori tanpa memahaminya (verbalism) maka akan menyebabkan tujuan pembelajaran tidak tercapai.

Melalui quantum learning peserta didik akan diajak belajar dalam suasana yang lebih nyaman dan menyenangkan, sehingga peserta didik akan lebih bebas menemukan berbagai pengalaman baru dalam belajarnya. Pembelajaran quantum learning sebagai salah satu metode, strategi, dan pendekatan pembelajaran khususnya menyangkut keterampilan guru dalam merancang, mengembangkan, dan mengelola sistem pembelajaran sehingga guru mampu menciptakan suasana pembelajaran yang efektif dan menyenangkan.

Alwiyah Abdurrahman (2009 : 14), istilah lain dari suggastology adalah accelerated
Learning atau "percepatan belajar", yakni metode yang memungkinkan peserta didik untuk belajar dalam kecepatan yang mengesankan dengan upaya yang normal dan diikuti dengan kegembiraan.

Pembelajaran quantum sebagai salah satu metode, strategi, dan pendekatan pembelajaran khususnya menyangkut keterampilan guru dalam merancang, mengembangkan, dan mengelola sistem pembelajaran sehingga guru mampu menciptakan suasana belajar yang efektif dan menyenangkan.

Pembelajaran quantum learning merupakan metode pembelajaran yang mengedepankan unsur-unsur kebebasan, santai dan menyenangkan serta indikator dalam pembelajaran quantum adalah peserta didik, sedangkan peranan guru adalah bertindak sebagai fasilitator dan moderator yang mengarahkan apa yang menjadi keinginan peserta didik dalam proses pembelajaran. Selain itu dalam pembelajaran quantum bisa menggunakan media audio (musik) yaitu musik klasik dimana musik ini dapat merangsang percepatan daya tangkap peserta didik sehingga mudah dalam memahami materi yang diberikan. Adapun langkah-langkah dari metode pembelajaran quantum learning dapat dilihat dalam tabel berikut:

Tabel 1. Langkah-Langkah Metode

Pembelajaran Quantum Learning

\begin{tabular}{llr}
\hline \multicolumn{1}{c}{ Fase } & \multicolumn{2}{c}{ Keterangan } \\
\hline Fase 1 & Tumbuhkan minat dengan \\
Kekuatan & memuaskan & "Apakah \\
AMBAK (Apa & Manfaatnya & BagiKu" \\
Manfaatnya Bagi & (AMBAK), dan manfaatkan \\
Ku). & kehidupan belajar. Ambak \\
& adalah motivasi yang \\
& didapat dari pemilihan \\
& secara mental antara \\
\hline
\end{tabular}




\begin{tabular}{|c|c|}
\hline & $\begin{array}{l}\text { manfaat dan akibat-akibat } \\
\text { suatu keputusan. }\end{array}$ \\
\hline $\begin{array}{l}\text { Fase } 2 \\
\text { Penataan } \\
\text { Lingkungan } \\
\text { Belajar. }\end{array}$ & $\begin{array}{l}\text { Seperti telah diungkapkan, } \\
\text { bahwa quantum learning } \\
\text { mementingkan adanya } \\
\text { lingkungan belajar yang } \\
\text { kondusif bagi pembelajar, } \\
\text { maka dalam proses belajar } \\
\text { dan mengajar diperlukan } \\
\text { penataan lingkungan yang } \\
\text { dapat membuat peserta } \\
\text { didik merasa betah dalam } \\
\text { belajarnya, dengan penataan } \\
\text { lingkungan belajar yang } \\
\text { tepat juga dapat mencegah } \\
\text { kebosanan dalam diri } \\
\text { peserta didik. }\end{array}$ \\
\hline $\begin{array}{l}\text { Fase } 3 \\
\text { Memupuk Sikap } \\
\text { Juara }\end{array}$ & $\begin{array}{l}\text { Banyak dari kita sebagai } \\
\text { pendidik telah memberikan } \\
\text { pujian positif bagi peserta } \\
\text { didik, pujian positif yang } \\
\text { diberikan bagi peserta } \\
\text { didik, tentunya akan } \\
\text { menumbuhkan sugesti } \\
\text { positif pula. Hal ini yang } \\
\text { akan mendorong sikap juara } \\
\text { bagi peserta didik }\end{array}$ \\
\hline $\begin{array}{l}\text { Fase } 4 \\
\text { Bebaskan Gaya } \\
\text { Belajar Siswa }\end{array}$ & $\begin{array}{l}\text { Ada berbagai macam gaya } \\
\text { belajar yang dipunyai oleh } \\
\text { peserta didik, gaya belajar } \\
\text { tersebut yaitu: visual, } \\
\text { auditorial dan kinestetik. } \\
\text { Dalam quantum learning } \\
\text { guru hendaknya } \\
\text { memberikan kebebasan } \\
\text { dalam belajar pada peserta } \\
\text { didiknya dan janganlah } \\
\text { terpaku pada satu gaya } \\
\text { belajar saja. Pemberian } \\
\text { instruksi yang tepat dan } \\
\text { sesuai dengan gaya belajar } \\
\text { peserta didik, tentunya akan } \\
\text { berpengaruh } \\
\text { keberhasilan pencapaian } \\
\text { tujuan peserta didik }\end{array}$ \\
\hline
\end{tabular}

\begin{tabular}{ll}
\hline & tersebut. \\
\hline Fase 5 & Belajar akan benar-benar \\
Membiasakan & dipahami sebagai aktivitas \\
Mencatat & kreasi ketika sang peserta \\
& didik tidak hanya bisa \\
& menerima, melainkan bisa \\
& mengungkapkan kembali \\
& apa yang didapatkan \\
& menggunakan bahasa hidup \\
& dengan cara dan ungkapan \\
& sesuai gaya belajar peserta \\
& didik itu sendiri. Hal \\
& tersebut dapat dilakukan \\
& dengan memberikan \\
& simbol-simbol atau gambar \\
& yang mudah dimengerti \\
& oleh peserta didik itu \\
& sendiri, simbol-simbol \\
& tersebut dapat berupa \\
& tulisan. \\
\hline Fase 6 & Salah satu aktivitas yang \\
Membiasakan & cukup penting adalah \\
Membaca & membaca. Karena dengan \\
& membaca akan menambah \\
& perbendaharaan kata, \\
& pemahaman, menambah \\
& wawasan dan daya ingat \\
akan bertambah. \\
\hline Fase 8 & Peserta didik yang kreatif \\
Melatih Kekuatan & adalah peserta didik yang \\
& ingin tahu, suka mencoba \\
dan senang bermain. \\
Lebih Kreatif
\end{tabular}




\section{METODOLOGI PENELITIAN}

Penelitian ini dilaksanakan di SMK Negeri 1 Stabat, yang beralamat di Jln. Kh.Wahid Hasyim, Kwala Bingai, Kec. Stabat, Kab. Langkat Prov. Sumatera Utara. Suharsimi Arikunto (2013 : 173), Populasi adalah keseluruhan subjek penelitian. Populasi dalam penelitian ini adalah seluruh siswa kelas X SMK Negeri 1 Stabat tahun pelajaran 2019/2020. Dimana jumlah seluruh populasinya adalah 464 siswa

Ibid (13), Sampel adalah sebagian atau wakil populasi yang diteliti. Pada penelitian ini teknik pengambilan sampel yang digunakan yaitu dengan teknik purposive sampling yaitu metode penetapan sampel dengan memilih beberapa sampel tertentu yang dinilai sesuai dengan tujuan atau masalah penelitian. Sampel dalam penelitian ini adalah kelas X-1 AK dan kelas X-2 AK dengan jumlah total sampel sebanyak 60 siswa. Sampel ini kemudian dibagi menjadi dua kelompok yaitu kelas X-1 AK sebagai kelompok eksperimen dan kelas X-2 AK sebagai kelompok kontrol.

Jenis penelitian ini adalah eksperimen semu (quasi eksperimen), karena tidak memungkinkan peneliti mengadakan pengontrolan penuh terhadap variabel kondisi eksperimen. Sampel penelitian ini akan dikelompokkan menjadi dua yaitu menjadi kelas eksperimen dan kelas kontrol kemudian diberikan perlakuan pembelajaran. Kelas eksperimen dalam proses pembelajarannya menggunakan metode quantum learning dengan alat peraga dan kelas kontrol diajarkan menggunakan model pembelajaran konvensional.

Karena jenis penelitian ini adalah eksperimen semu yang menggunakan dua kelompok yang diberi tes sebelum dan sesudah perlakuan maka desain penelitian ini dapat menggunkan desain eksperimen semu berupa pretest-postest control group design. Untuk lebih jelasnya dapat dilihat pada tabel di bawah ini.

Tabel 2. Desain Penelitian

Sugiyono (2012: 116),

\begin{tabular}{llll}
\hline Kelas & Pretest & Perlakuan & Posttest \\
\hline Eksperimen & $\mathrm{O}_{1}$ & $\mathrm{X}_{1}$ & $\mathrm{O}_{2}$ \\
\hline Kontrol & $\mathrm{O}_{1}$ & $\mathrm{X}_{2}$ & $\mathrm{O}_{2}$ \\
\hline
\end{tabular}

Menurut Sugiyono (2012) variabel adalah "segala sesuatu yang berbentuk apa saja yang ditetapkan oleh peneliti untuk dipelajari sehingga diperoleh informasi tentang hal tersebut, kemudian ditarik kesimpulanya," Dalam penelitian ini penulis menggunakan dua variabel yakni :

1. Variabel bebas (X) yaitu variabel yang mempengaruhi variabel terikat $(\mathrm{Y})$, variabel bebas (X) dalam penelitian ini adalah metode quantum learning dengan alat peraga.

2. Variabel terikat (Y) yaitu variabel yang dipengaruhi oleh variabel bebas $(\mathrm{X})$, variabel terikat (Y) dalam penelitian ini adalah kemampuan komunikasi matematis siswa.

\section{HASIL PENELITIAN DAN PEMBAHASAN}

Hasil penelitian yang dilaksanakan di SMK Negeri 1 Stabat yang beralamat di Jalan Kh.Wahid Hasyim, Kwala Bingai, Kec. Stabat, Kab. Langkat Prov. Sumatera Utara. Sampel penelitian pada penelitian ini terdiri dari dua kelas, yaitu kelas X-1 AK dan kelas X-2 AK dengan jumlah total sampel sebanyak 60 siswa. Sampel ini kemudian dibagi menjadi dua kelompok yaitu kelas X-1 AK sebagai kelas eksperimen dan kelas X-2 AK sebagai kelas kontrol. Penelitian ini bertujuan untuk mengetahui pengaruh metode quantum learning 
dengan menggunakan alat peraga terhadap kemampuan komunikasi matematis siswa kelas $\mathrm{X}$ SMK Negeri 1 Stabat tahun pelajaran 2019/2020. Kedua kelompok diberi perlakuan berbeda, kelas X-1 AK sebagai kelas eksperimen, yaitu kelompok yang mendapatkan pembelajaran dengan menggunakan metode quantum learning dengan menggunakan alat peraga. Sedangkan kelas X-2 AK sebagai kelas kontrol, yaitu kelompok yang mendapatkan pembelajaran dengan menggunakan model pembelajaran konvensional.

Sebelum kedua kelas diberi perlakuan yang berbeda, kedua kelas tersebut diberikan tes awal yaitu pretest untuk mengetahui kemampuan awal siswa dan setelah kedua kelas diberi perlakuan, pertemuan berikutnya peneliti memberikan tes akhir yaitu postest untuk mengetahui kemampuan komunikasi matematis siswa setelah diberikan perlakuan. Untuk distribusi frekuensi nilai hasil pretest kemampuan komunikasi matematis siswa kelas eksperimen dan kelas control.

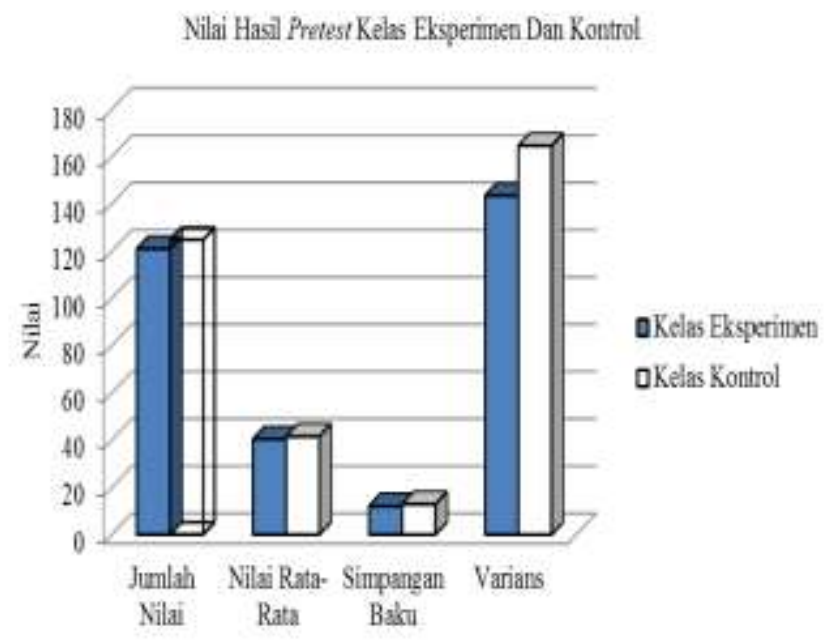

Gambar .1 Nilai Hasil Pretest Kelas Eksperimen Dan Kontrol
Tabel 3. Distribusi Nilai Hasil Postest Kelas

Eksperimen Dan Kontrol

\begin{tabular}{|c|c|c|}
\hline $\begin{array}{l}\text { Hasil } \\
\text { Postest } \\
\text { Kelas } \\
\text { Eksper }\end{array}$ & & $\begin{array}{l}\text { Hasil } \\
\text { Postest } \\
\text { Kelas } \\
\text { Kontrol }\end{array}$ \\
\hline $\begin{array}{l}\text { Interval } \\
\text { Nilai }\end{array}$ & $\begin{array}{l}\text { Freku Interval } \\
\text { enssi Nilai }\end{array}$ & $\begin{array}{l}\text { Freku } \\
\text { enssi }\end{array}$ \\
\hline $16-25$ & $16-25$ & 5 \\
\hline $26-35$ & $8 \quad 26-35$ & 4 \\
\hline $36-45$ & $9 \quad 36-45$ & 11 \\
\hline $46-55$ & $46-55$ & 4 \\
\hline $56-65$ & $56-65$ & 6 \\
\hline $\begin{array}{l}\text { Jumlah } \\
\text { Nilai }\end{array}$ & $1209 \quad \begin{array}{l}\text { Jumlah } \\
\text { Nilai }\end{array}$ & 1248 \\
\hline $\begin{array}{l}\text { Rata- } \\
\text { Rata } \\
\end{array}$ & $\begin{array}{ll} & \text { Rata- } \\
40,30 & \text { Rata } \\
\end{array}$ & 41,47 \\
\hline $\begin{array}{l}\text { Simpa- } \\
\text { ngan } \\
\text { Baku }\end{array}$ & $\begin{array}{ll}\text { Simpa- } \\
\text { ngan } \\
11,975 \text { Baku }\end{array}$ & 12.827 \\
\hline Varian & s 143,40 Varian & $\begin{array}{ll}\mathbf{S} & 164.53\end{array}$ \\
\hline
\end{tabular}

Berdasarkan tabel dan gambar tersebut dapat diketahui bahwa jumlah nilai pretest kelas eksperiemen sebesar 1209 sedangkan jumlah nilai pretest kelas kontrol sebesar 1248, nilai rata-rata pretest kelas eksperimen sebesar 40.30 sedangkan nilai rata-rata pretest kelas kontrol sebesar 41,47. Nilai simpangan baku kelas eksperimen sebesar 11,97 sedangkan nilai simpangan baku kelas kontrol sebesar 12,82 dan nilai varians kelas eksperimen sebesar 143,4 sedangkan nilai varians kelas kontrol sebesar 164,53. Berdasarkan nilai-nilai tersebut dapat disimpulkan bahwa kedua kelas memiliki kemampuan komunikasi msatematis yang tidak jauh berbeda.

Untuk distribusi frekuensi nilai hasil postest kemampuan komunikasi matematis siswa kelas 
eksperimen dan kelas kontrol dapat dilihat pada tabel di bawah ini.

Tabel 4. Distribusi Nilai Hasil Postest Kelas Eksperimen Dan Kontrol

\begin{tabular}{|c|c|c|}
\hline $\begin{array}{l}\text { Hasil } \\
\text { Postest } \\
\text { Kelas } \\
\text { Eksper }\end{array}$ & & $\begin{array}{l}\text { Hasil } \\
\text { Postest } \\
\text { Kelas } \\
\text { Kontrol }\end{array}$ \\
\hline $\begin{array}{l}\text { Interval } \\
\text { Nilai }\end{array}$ & $\begin{array}{l}\text { Freku Interval } \\
\text { enssi Nilai }\end{array}$ & $\begin{array}{l}\text { Freku } \\
\text { enssi }\end{array}$ \\
\hline $60-69$ & $20-29$ & 4 \\
\hline $70-79$ & $30-39$ & 8 \\
\hline $80-89$ & $40-49$ & 4 \\
\hline $90-99$ & $50-59$ & 8 \\
\hline & 60-69 & 6 \\
\hline $\begin{array}{l}\text { Jumlah } \\
\text { Nilai }\end{array}$ & $\begin{array}{ll} & \text { Jumlah } \\
2466 & \text { Nilai }\end{array}$ & 1316 \\
\hline $\begin{array}{l}\text { Rata- } \\
\text { Rata }\end{array}$ & $\begin{array}{ll}\text { Rata- } \\
82,20 & \begin{array}{c}\text { Rata } \\
\text { Rata }\end{array}\end{array}$ & 43,87 \\
\hline $\begin{array}{l}\text { Simpa- } \\
\text { ngan } \\
\text { Baku }\end{array}$ & $\begin{aligned} & \begin{array}{l}\text { Simpa- } \\
\text { ngan }\end{array} \\
11,20 & \text { Baku }\end{aligned}$ & 14,15 \\
\hline
\end{tabular}

\section{Varians 121,48 Varians 200,48}

Berdasarkan tabel tersebut dapat diketahui bahwa jumlah nilai postest kelas eksperiemen sebesar 2466 sedangkan jumlah nilai postest kelas kontrol sebesar 1316, nilai rata-rata postest kelas eksperimen sebesar 82,20 sedangkan nilai rata-rata postest kelas kontrol sebesar 43,87. Nilai simpangan baku kelas eksperimen sebesar 11,02 sedangkan nilai simpangan baku kelas kontrol sebesar 14,15 dan nilai varians kelas eksperimen sebesar 121,48 sedangkan nilai varians kelas kontrol sebesar 200,48. Berdasarkan nilai-nilai tersebut dapat disimpulkan bahwa kedua kelas memiliki kemampuan komunikasi matematis yang jauh berbeda.
Selanjutnya data hasil pretest dan postest kemampuan komunikasi matematis siswa kelas $X$ SMK Negeri 1 Stabat tahun pelajaran 2019/2020 yang dijadikan sebagai sampel penelitian akan dianalisis untuk mengetahui kenormalan data, homogenitas, persesamaan regresi dan hasil uji hipotesisnya.

\section{Uji Normalitas}

Uji normalitas dilakukan untuk mengetahui apakah data sampel yang diteliti berdistribusi normal atau tidak. Pengujian normalitas dilakukan dengan menggunakan kolmogrov smirnov. Syarat normal yang harus dipenuhi adalah nilai signifikansi (Sig.) > 0,05 menunjukkan bahwa data berdistribusi secara normal. Data hasil pretest dan postest kemampuan komunikasi matematis siswa X SMK Negeri 1 Stabat tahun pelajaran 2019/2020 yang dijadikan sebagai sampel penelitian berdistribusi normal seperti yang ditunjukkan pada tabel berikut.

Tabel 5. Ringkasan Hasil Uji Normalitas Data Pretest Dan Postest

\begin{tabular}{|c|c|c|c|}
\hline $\begin{array}{c}\text { Kelas Nilai } \\
\text { Sign } \\
\text { Pretest } \\
\end{array}$ & $\begin{array}{l}\text { Krit } \\
\text { ria }\end{array}$ & $\begin{array}{l}\text { Nilai } \\
\text { Sign } \\
\text { Postest }\end{array}$ & Kriteria \\
\hline $\begin{array}{ll}\text { Eks } & 0.64> \\
& 0,05\end{array}$ & $\begin{array}{l}\text { Nor } \\
\text { mal }\end{array}$ & $\begin{array}{l}0.42> \\
0,05\end{array}$ & Normal \\
\hline $\begin{array}{c}\text { Kontr } 0.24> \\
0,05\end{array}$ & $\begin{array}{l}\text { Nor } \\
\text { mal }\end{array}$ & $\begin{array}{l}0.26> \\
0,05\end{array}$ & Normal \\
\hline
\end{tabular}

\section{Uji Homogenitas}

Pengujian homogenitas data dilakukan dengan uji kesamaan varians. Uji homogenitas dilakukan dengan uji levene's test pada sofware SPSS 16. Data untuk setiap variabel penelitian dikatakan homogen apabila nilai signifikansi (Sig.) > 0,05. Hasil uji homgenitas data hasil 
pretest dan postest kemampuan komunikasi matematis siswa X SMK Negeri 1 Stabat tahun pelajaran 2019/2020 yang dijadikan sebagai sampel penelitian ternyata homogen seperti yang ditunjukkan pada tabel berikut.

Tabel 6. Ringkasan Hasil Uji Homogenitas Data Pretest Dan Postest

\begin{tabular}{llll}
\hline $\begin{array}{l}\text { Nilai } \\
\text { Sign } \\
\text { Pretest }\end{array}$ & $\begin{array}{l}\text { Krit } \\
\text { eria }\end{array}$ & $\begin{array}{l}\text { Nilai } \\
\text { Sign } \\
\text { Postest }\end{array}$ & $\begin{array}{l}\text { Krite } \\
\text { ria }\end{array}$ \\
\hline $0,71>0,05$ & Homog & $0,13>$ & Homog \\
& en & 0,05 & en \\
\hline
\end{tabular}

\section{Uji Regresi Linear Sederhana}

Analisis regresi sederhana adalah sebuah metode pendekatan untuk pemodelan hubungan antara satu variabel dependen dan satu variabel independen. Dalam analisis regresi linear sederhana, hubungan antara variabel bersifat linier, dimana perubahan pada variabel $\mathrm{X}$ akan diikuti oleh perubahan pada variabel $\mathrm{Y}$ secara tetap. Data yang digunakan untuk melakukan analisis regresi sederhana adalah data hasil pretest dan postest. Hasil uji regresi linear sederhana kemampuan komunikasi matematis kelas eksperimen disajikan dalam tabel dibawah ini.

Tabel 7. Hasil Analisis Regresi Linear Sederhana Kelas Eksperimen Unstandardized Standardized Coefficients

\begin{tabular}{|c|c|c|c|c|c|}
\hline \multicolumn{6}{|c|}{ Std } \\
\hline & B & Eror & Beta & $\mathrm{t}$ & Sig \\
\hline 1 (Constant) & 46.340 & 1.867 & & 24.821 & .0 \\
\hline Koef. Ekspe & r. 890 & .044 & .967 & 20.011 & .0 \\
\hline
\end{tabular}

Berdasarkan Tabel di atas diperoleh nilai signifikansi $0,000<0,05$, maka model regresi dapat dipakai untuk memprediksi variabel terikat (variabel Y) jika variabel bebasnya (variabel X) dimanipulasi. Untuk nilai konstanta regresi didapat nilai 46,34 dan nilai koefisien regresi sebesar 0,89. Sehingga dari nilai-nilai tersebut (konstanta dan koefisien) dapat dibentuk sebuah persamaan regresi linear yaitu $\mathrm{Y}=46,34$ $+0,89 \mathrm{X}$, artinya setiap terdapat satu kenaikan nilai variabel $\mathrm{X}$ maka nilai variabel $\mathrm{Y}$ bertambah sebesar 0,89 dan persamaan regresi bernilai positif yang artinya jika penerapan metode quantum learning dengan menggunakan alat peraga baik maka kemampuan komunikasi matematis siswa juga akan baik.

Untuk hasil uji regresi linear sederhana kemampuan komunikasi matematis kelas kontrol disajikan dalam tabel dibawah ini.

Tabel 8. Hasil Analisis Regresi Linear Sederhana Kontrol

\begin{tabular}{|c|c|c|c|c|c|}
\hline \multicolumn{6}{|c|}{$\begin{array}{l}\text { Unstandardized Standardized } \\
\text { Coefficients }\end{array}$} \\
\hline & & Std & & & \\
\hline & B & Eror & Beta & $\mathrm{t}$ & Sig \\
\hline 1(Constant & t) -.358 & 2.330 & & -.154 & .0 \\
\hline Kontrol & 1.067 & 7.054 & 96615 & 9.840 & .0 \\
\hline
\end{tabular}

Berdasarkan Tabel di atas diperoleh nilai signifikansi $0,000<0,05$, maka model regresi dapat dipakai untuk memprediksi variabel 
terikat (variabel Y) jika variabel bebasnya (variabel X) dimanipulasi. Untuk nilai konstanta regresi didapat nilai $-0,35$ dan nilai koefisien regresi sebesar 1.06. Sehingga dari nilai-nilai tersebut (konstanta dan koefisien) dapat dibentuk sebuah persamaan regresi linear yaitu $\mathrm{Y}=-0,35$ $+1,06 \mathrm{X}$, artinya setiap terdapat satu kenaikan nilai variabel $\mathrm{X}$ maka nilai variabel $\mathrm{Y}$ bertambah sebesar 1,06 dan persamaan regresi bernilai positif yang artinya jika penerapan model konvensional baik maka kemampuan komunikasi matematis siswa juga akan baik.

\section{Uji Hipotesis}

Pengambilan keputusan terhadap hasil uji hipotesis yang diperoleh dilakukan pada taraf siginifikansi $5 \%$ atau 0,05 . Jika nilai $t_{\text {hitung }} \leq$ $\mathrm{t}_{\text {tabel}}$, artinya menerima $\mathrm{H}_{0}$ dan jika nilai $\mathrm{t}_{\text {hitung }}>$ $t_{\text {tabel }}$ maka menerima $\mathrm{H}_{\mathrm{a}}$. Hipotesis yang diajukan dalam penelitian ini adalah terdapat pengaruh metode quantum learning beserta alat peraga terhadap kemampuan komunikasi matematis siswa pada materi fungsi dan relasi siswa kelas $\mathrm{X}$ SMK Negeri 1 Stabat tahun pelajaran 2019/2020. Berdasarkan hasil perhitungan uji hipotesis independent $\mathrm{T}$ test diperoleh nilai $\mathrm{t}_{\text {hitung }}$ sebesar 11,7 dan nilai tabel untuk jumlah sampel 60 siswa dengan nilai probabilitas $5 \%$ adalah 2,00 . Nilai $t_{\text {hitung }}$ dan $t_{\text {tabel }}$ ini dibandingkan sehingga diperoleh $t_{\text {hitung }}>t_{\text {tabel }}$ yaitu 11,7 $>2,00$ artinya hipotesis yang diajukan dalam penelitian ini dapat diterima yaitu terdapat pengaruh metode quantum learning beserta alat peraga terhadap kemampuan komunikasi matematis siswa pada materi fungsi dan relasi siswa kelas X SMK Negeri 1 Stabat tahun pelajaran 2019/2020.

\section{Pembahasan Hasil Penelitian}

Penelitian ini dilaksanakan di SMK Negeri

1 Stabat, dengan sampel penelitiannya adalah siswa kelas X-1 AK sebagai kelas eksperimen dan kelas X-2 AK sebagai kelas kontrol. Kelas eksperimen adalah kelas yang diberikan pembelajaran dengan metode pembelajaran quantum learning beserta alat peraga, sedangkan kelas kontrol adalah kelas yang diberikan pembelajaran dengan model pembelajaran konvensional. Jenis penelitain ini adalah penelitian eksperimen semu yang menggunakan dua kelompok yang diberi tes sebelum dan sesudah perlakuan (pretest-postest control group design). Tes tersebut merupakan tes kemampuan komunikasi matematis sebanyak lima soal yang bertujuan untuk mengukur kemampuan komunikasi matematis siswa. Sebelum kedua kelompok atau kelas diberikan perlakuan yang berbeda terlebih dahulu diberikan pretest kemampuan komunikasi matematis kemudian barulah diberikan perlakuan yang berbeda yaitu pemberian pembelajaran dengan metode pembelajaran quantum learning beserta alat peraga pada siswa kelas X-1 AK dan pemberian pembelajaran dengan model pembelajaran konvensional pada siswa kelas X-2 AK. Setelah diberikan perlakuan tersebut maka kedua kelas diberikan postest kemampuan komunikasi matematis, sehingga data dalam penelitian ini berasal dari nilai pretest dan postest kemampuan komunikasi matematis kelas eksperimen dan kelas kontrol.

Setelah data pretest dan postest kemampuan komunikasi matematis kelas eksperimen dan kelas kontrol diperoleh maka data-data tersebut di analisis dengan bantuan software aplikasi komputer SPSS 16 yang meliputi analisis normalitas data, homogenitas data, analisis regresi linear sederhana dan analisis independent $\mathrm{T}$ test yang digunakan untuk menguji hipotesis yang diajukan dalam penelitian ini. Hasil analisis data pretest dan 
postest kemampuan komunikasi matematis kelas eksperimen dan kelas kontrol diketahui bahwa data-data tersebut berdistribusi secara normal dan homogen.

Berdasarkan nilai hasil pretest kemampuan komunikasi matematis kelas eksperimen diperoleh nilai rata-rata sebesar 40,30 sedangkan nilai hasil postest kemampuan komunikasi matematis kelas eksperimen diperoleh nilai ratarata sebesar 82,20 atau mengalami peningkatan sebesar 41,9. Peningkatan tersebut dikarenakan pada kelas eksperimen diberikan pembelajaran dengan metode pembelajaran quantum learning beserta alat peraga. Penerapan metode quantum learning yang dipadukan dengan penggunaan alat peraga pada kelas eksperimen yang dilakukan oleh peneliti pada tahap awal adalah menyajikan serangkaian pertanyaan yang sifatnya menuntun dan menggali namun pada awal pertemuan pembelajaran para siswa masih belum terbiasa dengan metode quantum learning sehingga sedikit menghambat jalannya proses pembelajaran namun dalam pertemuan selanjutnya sudah tampak proses berpikir siswa yang mengaitkan pengetahuan setiap siswa dan pengalamannya dengan pengetahuan baru yang sedang dipelajari, dengan digunakannya alat peraga dalam menjelaskan materi dan contohcontoh soal relasi dan fungsi terlihat antusiasme siswa dalam mengikuti proses pembelajaran. Dengan adanya alat peraga, siswa akan lebih banyak mengikuti pelajaran dengan gembira, sehingga minatnya dalam mempelajari matematika semakin besar. Siswa akan senang, terangsang, tertarik dan bersikap positif terhadap materi matematika.

Berdasarkan data pretest dan postest kelas eksperimen tersebut juga dapat ditentukan persamaan regresinya yaitu $\mathrm{Y}=46,34+0,89 \mathrm{X}$. Arti dari persamaan regresi tersebut adalah jika terdapat satu kenaikan nilai variabel $\mathrm{X}$ maka nilai variabel $\mathrm{Y}$ bertambah sebesar 0,89 dan karena persamaan regresi bernilai positif dapat diartikan bahwa seandainya penerapan metode quantum learning dengan menggunakan alat peraga baik maka kemampuan komunikasi matematis siswa juga akan baik.

Untuk nilai hasil pretest kemampuan komunikasi matematis kelas kontrol diperoleh nilai rata-rata sebesar 41,47 sedangkan nilai hasil postest kemampuan komunikasi matematis kelas kontrol diperoleh nilai rata-rata sebesar 43,87 atau hanya mengalami peningkatan sebesar 2,4. Peningkatan nilai rata-rata yang sangat kecil tersebut disebabkan kelas kontrol hanya memperoleh pembelajaran dengan model konvensional. Penerapan model pembelajaran konvensional yang dilakukan peneliti pada kelas kontrol mengakibatkan pengetahuan yang dimiliki siswa akan terbatas pada apa yang diberikan peneliti, proses pembelajaran di dominasi oleh peneliti sehingga tidak terjadi pengalaman belajar bagi siswa. Selama proses pembelajaran berlangsung, siswa hanya mendengar dan mencatat apa yang disampaikan oleh peneliti, tidak terjadi diskusi antara siswa dengan guru maupun antar sesama siswa, disamping itu juga selama peneliti melakuakan pembelajaran pada kelas kontrol selalu saja ditemukan siswa yang tidak serius dalam mengikuti pelajaran.

Berdasarkan data pretest dan postest kelas kontrol tersebut juga dapat ditentukan persamaan regresinya yaitu $\mathrm{Y}=-0,35+1,06 \mathrm{X}$, artinya setiap terdapat satu kenaikan nilai variabel $X$ maka nilai variabel $\mathrm{Y}$ bertambah sebesar 1,06 namaun jika nilai $X=0$ maka nilai $Y=-0,35$. Meskipun demikian persamaan regresi pada kelas kontrol bernilai positif yang artinya jika penerapan model konvensional baik maka 
kemampuan komunikasi matematis siswa juga akan baik.

Dari uraian di atas dapat diketahui bahwa metode quantum learning dengan alat peraga dapat memberikan pengaruh yang lenih baik, berupa peningkatan kemampuan komunikasi matematis siswa kelas eksperimen namun tidak demikian dengan kelompok kelas kontrol yang menggunkan model pembelajaran konvensional. Hal ini didasarkan pada perbedaan nilai rata-rata hasil postest kedua kelas. Berdasarkan nilai ratarata hasil postest kedua kelas diketahui bahwa nilai rata-rata postest kelas ekperimen lebih unggul dibandingkan kelas kontrol yaitu 82,2 pada kelas eksperimen dan 43,8 pada kelas kontrol. Hasil uji hipotesis yang diperoleh yaitu $t_{\text {hitung }}>t_{\text {tabel }}(11,7>2,00)$ sehingga dapat disimpulkan bahwa terdapat pengaruh metode quantum learning dengan menggunakan alat peraga terhadap kemampuan komunikasi matematis siswa kelas X SMK Negeri 1 Stabat tahun pelajaran 2019/2020.

\section{Temuan Penelitian}

Penulis menyadari bahwa penelitian ini belum sempurna. Berbagai upaya sudah dilakukan untuk mendapatkan hasil yang optimal namun masih ada saja beberapa faktor yang sulit dikendalikan, yaitu :

1. Penggunaan metode quantum learning dengan alat peraga dalam pembelajaran terlihat bahwa sebagian siswa masih belum terbiasa dengan metode pembelajaran tersebut.

Aktivitas siswa di dalam kelas kurang kondusif karena tugas yang diberikan dibuat dalam bentuk diskusi kelompok, sedangkan siswa sebelumnya tidak pernah mengerjakan tugas dalam diskusi kelompok.

2. Saat mengerjakan lembar aktivitas siswa (LAS) secara berkelompok, terdapat beberapa kelompok tidak membahas lembar aktivitas siswa (LAS) yang diberikan melainkan hanya bercerita dan bercanda.

3. Masih terlihat beberapa siswa yang tidak dapat berperan aktif dalam proses pengerjaan tugas kelompok seakan tidak perduli dengan kegiatan yang ada.

Alokasi waktu pembelajaran yang tersedia tidak dapat digunakan sesuai dengan alokasi waktu yang telah ditetapkan dalam pembelajaran sehingga diperlukan persiapan dan penggunaan alokasi waktu yang lebih baik.

Dengan adanya temuan ini peneliti beranggapan untuk menelisik model yang semestinya dilakukan oleh peran seorang guru dengan menggunakan Quantum Teaching. Quantum Teaching menawarkan cara-cara baru untuk memaksimalkan dampak usaha pengajaran yang dilakukan guru melalui perkembangan hubungan, pengubahan belajar, dan penyampaian kurikulum.Terjadinya peningkatan ini dikarenakan pembelajaran dengan model Quantum Teaching memberikan kebebasan siswa berekspresi sehingga pemahaman yang didapat siswa khususnya tentang materi pelajaran Biologi lebih dalam dan berkesan. Dalam proses belajar mengajar guru menggunakan cara-cara yang efektif dan menarik, diantaranya dengan cara menerapkan kerangka pengajaran TANDUR yaitu: Tumbuhkan, Alami, Namai, Demostrasikan, Ulangi, dan Rayakan. Sehingga penerimaan siswa terhadap pelajaran lebih menyenangkan dan berkesan. Berdasarkan hasil observasi aktivitas mengajar guru, tahapantahapan kerangka TANDUR terlaksana dengan baik dan juga dari hasil observasi aktivitas belajar siswa pada setiap tahapan model pembelajaran Quantum Teaching siswa terlihat aktif dalam mengikuti pelajaran. Terlihat dari perhatian siswa terfokus pada proses pembelajaran yaitu dengan banyaknya pertanyaan yang diajukan siswa dan juga peran aktif siswa dalam kelompoknya (Sitepu, 2019). 


\section{KESIMPULAN DAN SARAN}

\section{A. Kesimpulan}

Berdasarkan hasil uji hipotesis dengan teknik uji $t$ diperoleh nilai $t_{\text {hitung }}>t_{\text {tabel }}$ yaitu $11,00>2,00$ sehingga dapat diambil kesimpulan bahwa terdapat pengaruh metode quantum learning dengan menggunakan alat peraga terhadap kemampuan komunikasi matematis siswa kelas X SMK Negeri 1 Stabat tahun pelajaran 2019/2020. Nilai rata-rata kemampuan komunikasi matematis siswa kelompok kelas eksperimen setelah mengikuti serangkaian proses pembelajaran dengan metode quantum learning dan alat peraga mengalami peningkatan yang sangat signifikant yakni 40,3 meningkat mejadi 82.2 dan tidak terdapat peningkatan yang signifikant pada kelompok kelas kontrol yang menggunakan model pembelajaran konvensional yakni 41,47 menjadi 43,87. Hal ini disebabkan dalam model pembelajaran konvensional, proses pembelajaran berjalan membosankan, siswa menjadi pasif dan hanya menulis saja maka pengetahuan yang diperoleh mudah dilupakan dan siswa hanya belajar menghafal tanpa pemahaman.

\section{B. Saran}

Berdasarkan kesimpulan hasil penelitian, maka penulis menyampaikan saran sebagai berikut :

1. Bagi siswa, sebaiknya siswa melibatkan diri secara aktif dalam membangun pengetahuan, meningkatkan kemampuan komunikasi matematika serta memperoleh pengalaman belajar yang baru, bermakna dan menyenangkan.
2. Bagi guru, agar dapat menerapkan metode quantum learning dan alat peraga atau metode pembelajaran lainnya yang dapat meningkatkan kemampuan komunikasi matematika siswa dalam usaha perbaikan proses pembelajaran.

3. Bagi peneliti, menambah pengalaman serta wawasan baik dalam bidang penulisan maupun penelitian dan bagi peneliti selanjutnya dapat melakukan pengembangan penelitian selanjutnya yang relevan dengan penelitian ini dan dapat menggunakan hasil penelitian ini sebagai bahan referensi ataupun perbandingan.

4. Bagi sekolah, sebaiknya meninjau kembali apakah metode quantum learning dan alat peraga yang dapat meningkatkan kemampuan komunikasi matematika siswa digunakan kembali dalam proses pembelajaran di sekolah atau tidak.

\section{DAFTAR PUSTAKA}

Abdurrrahman, Alwiyah. 2009. Quantum Learning: Membiasakan Belajar Nyaman dan Menyenangkan, terjemahan Quantum Learning by Bobbi DePorter \& Mike Hernacki. Bandung: Kaifa.

Arikunto, Suharsimi. 2013. Prosedur Penelitian Suatu Pendekatan Praktik. Jakrata: Rineka Cipta.

Depdikdas. 2003. Undang-Undang Republik Indonesia Nomor 20 Tahun 2003 Tentang Sistem Pendidikan Nasional. Jakarta: CV Eko Jaya.

Dharma. 2019. Penerapan Model Pembelajaran Tps (Think-Pair-Share) Untuk Meningkatkan Kemampuan Komunikasi Matematis Dan Percaya Diri Peserta Didik Kelas X Mipa 1 Sma Negeri 6 Semarang Pada Materi Sistem Persamaan Linear Tiga Variabel Tahun Pelajaran 2018/2019. Jurnal PRISMA Vol. 2. 
Hartini, dkk. Penerapan Model Pembelajaran Think-Pair-Share untuk Meningkatkan Kemampuan Komunikasi Matematis Siswa SMP. Kreano No. 7. Vol 2.

National Council of Teachers of Mathematics. 2000. Principles and Standards for School Mathematics. United States of America: Library of Congress Cataloguing-inPublication.

Rahardi, Aristo. 2004. Media Pembelajaran. Jakarta: Dirjen Dikdasmen.

Rahman, Abdur. dkk. 2016. Matematika-Studi dan Pengajaran. Jakarta : Kemdikbud.

Rifa'i dan Anni. 2012. Psikologi Pendidikan. Semarang :UPT Unnes Press.

Sitepu, Br. D.R. 2019. Prosiding Seminar Nasional Multidisiplin Ilmu Universitas Asahan ke Tema : "Peran Ilmu Pengetahuan Dalam Pembangunan Di Era Revolusi Industri 4.0 Bedasarkan Kearifan Lokal.:Penerapan Model Quantum Teaching Pada Pembelajaran Biologi Materi Pokok Sistem Ekskresi Manusia
Di Kelas XI IPA Sma Swasta Esa Prakarsa. Hal. 63-71

Suderadjat, Hari. 2004. Implementasi Kurikulum Berbasis Kompetensi $(K B K)$. Bandung: $\mathrm{CV}$ Cipta Cekas Grafika. 